\title{
Vendor Assessment for the Waste Package Closure System (Yucca Mountain Project)
}

September 2003

Idaho National Engineering and Environmental Laboratory Bechtel BWXT Idaho, LLC 
INEEL/EXT-03-00861

Project No. 23306

\section{Vendor Assessment for the Waste Package Closure System (Yucca Mountain Project)}

September 2003

Idaho National Engineering and Environmental Laboratory Idaho Falls, Idaho 83415

Prepared for the

U.S. Department of Energy

Assistant Secretary for Environmental Management

Under DOE Idaho Operations Office

Contract DE-AC07-99ID13727 


\begin{abstract}
The Idaho National Engineering and Environmental Laboratory (INEEL) has been tasked with developing, designing, constructing, and operating a fullscale prototype of the work package closure system. As a precursor to developing the conceptual design, all commercially available equipment was assessed to identify any existing technology gaps. This report presents the results of that assessment for all major equipment.
\end{abstract}




\begin{abstract}
AUTHORS
The following people (listed alphabetically) provided significant contributions in preparing this document; their assistance was invaluable.

Contributors from the INEEL:

\author{
S. Michael Berry \\ Rodney J. Bitsoi \\ Kevin M. Croft \\ Dennis C. Kunerth \\ Timothy R. McJunkin \\ David P. Pace \\ Colleen Shelton-Davis \\ Rodney M. Shurtliff \\ Herschel B. Smartt \\ Derek C. Wadsworth \\ Arthur D. Watkins
}




\section{CONTENTS}

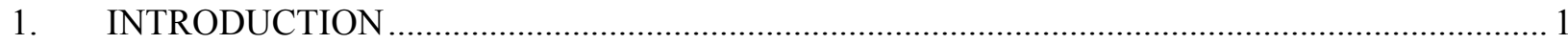

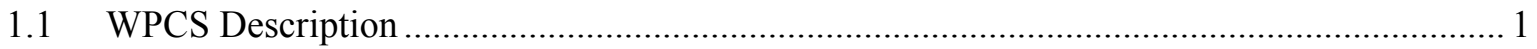

2. OPERATION AND TECHNICAL REQUIREMENTS …...................................................... 5

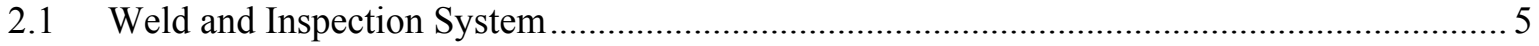

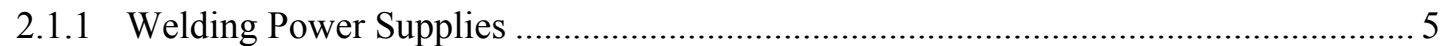

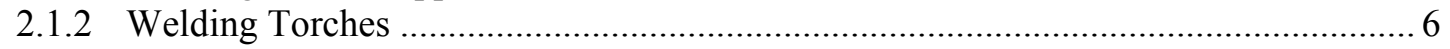

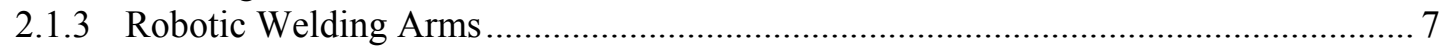

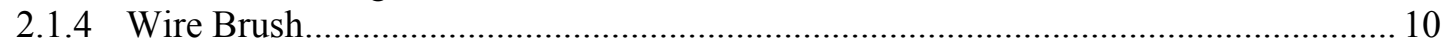

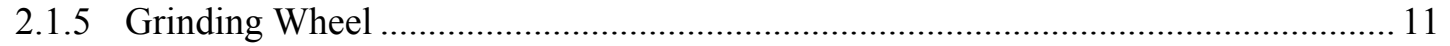

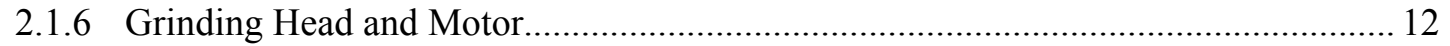

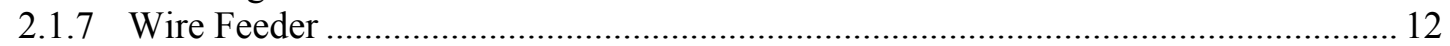

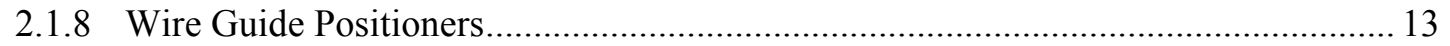

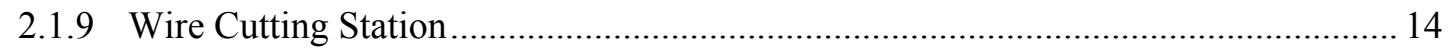

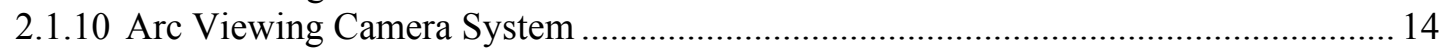

2.1.11 Seam Tracking/Quantitative Visual Topography Inspection................................... 16

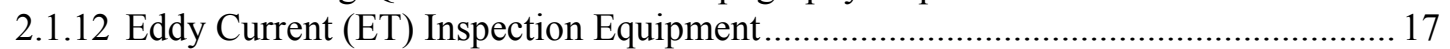

2.1.13 Ultrasonic Nondestructive Examination Equipment ................................................ 20

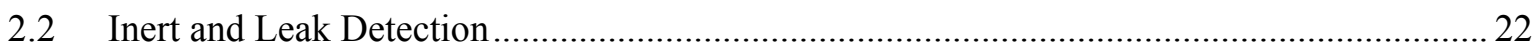

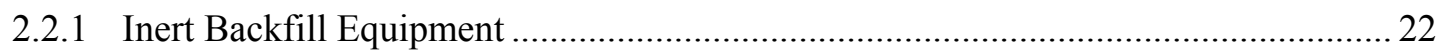

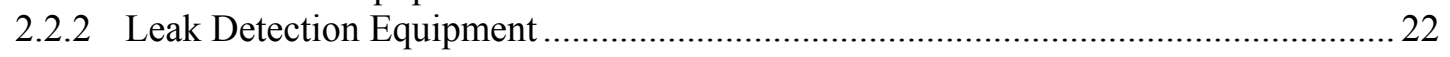

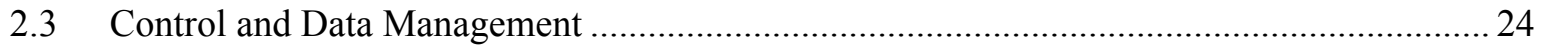

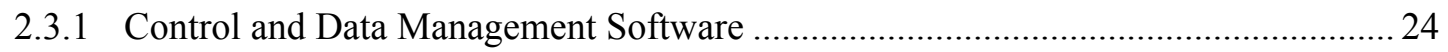

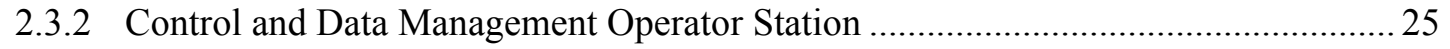

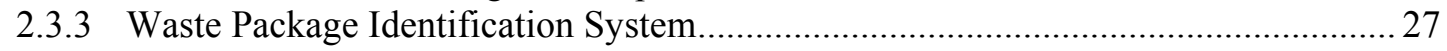

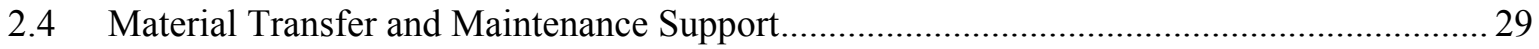

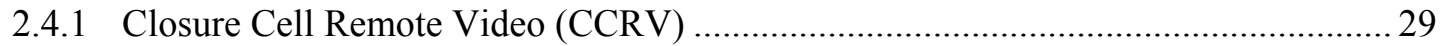

2.4.2 Overhead Closure Support Area Crane ……................................................................ 31

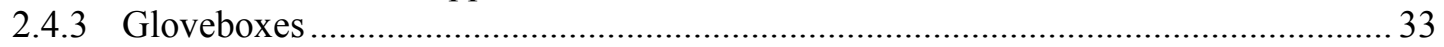

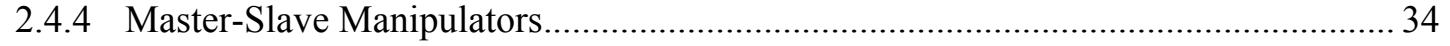

2.4.5 Overhead Electro-Mechanical Manipulator ….......................................................... 35

\section{FIGURES}

Figure 1. Second floor layout of the closure areas within the Dry Transfer Facility................................ 2

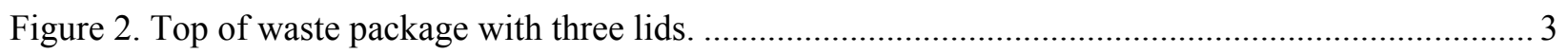

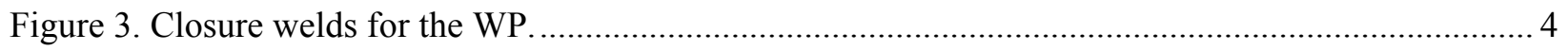




\section{TABLES}

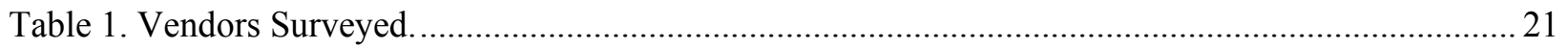




\section{ACRONYMS}

DOE U.S. Department of Energy

INEEL Idaho National Engineering and Environmental Laboratory

WPCS Waste Package Closure System

WP waste package

CCD charged coupled device

CMOS complimentary metal oxide semiconductor

Vac volts alternating current

TCP/IP Transmission Control Protocol/Internet Protocol

SCARA selective compliance automatic robotic arm

CRL Central Research Laboratories

ARO after receipt of order

ACECO American Crane and Equipment Company

GTAW gas tungsten arc welding 


\section{Vendor Assessment for the Waste Package Closure System (Yucca Mountain Project)}

\section{INTRODUCTION}

The U.S. Department of Energy (DOE) is responsible for accepting and disposing of spent nuclear fuel and high-level waste in a geological repository. To meet this responsibility, these materials will be sealed inside waste packages (WP) and disposed of at the DOE owned Yucca Mountain site in Nevada (operated by Bechtel SAIC Company, LLC), pending a Nuclear Regulatory Commission license approval. The Idaho National Engineering and Environmental Laboratory (INEEL) has been tasked with developing, designing, constructing, and operating a full-scale prototype of the WP closure system (WPCS). WP closure operations will include (a) welding and nondestructive examination of one stainlesssteel lid, two Alloy 22 lids, and one stainless steel purge port cap; (b) purging and filling the inner container with an inert gas; and (c) mitigating stress on the final weld. Due to the high radiation fields associated with spent nuclear fuel and high-level waste, all processes will be performed remotely.

In preparing for the conceptual design of the WPCS, commercially available equipment was assessed to identify any technology gaps that may exist. This report presents the results of that assessment for all major equipment. Development activities to fill these gaps will be performed by the INEEL, by a commercial vendor, or by a combination of both. By involving a vendor early in the project, the likelihood of equipment being readily available for construction of the facility by Bechtel SAIC Company, LLC is increased. As the detailed design progresses, a few minor items may be identified that will need some development as well; however, these should not significantly impact the overall project.

\subsection{WPCS Description}

The initial WPCS is located within the Dry Transfer Facility. It consists of three WP stations on the first floor, three closure cells, a closure support area, a closure operating corridor, two closure maintenance areas on the second floor, and a maintenance facility on the third floor. Figure 1 shows the general layout of the closure areas on the second floor within the Dry Transfer Facility.

The WP consists of two vessels (see Figure 2), an inner modified Type 316L stainless-steel vessel and an outer Alloy 22 shell. After the WP has been loaded with spent nuclear fuel/high-level waste and the stainless-shell lid (inner shell top lid assembly) is inserted on the inner vessel, the WP is sent to the WPCS. The inner lid is mechanically retained by a spread ring consisting of one or two segments. A twopass seal weld will be made between the spread ring and the inner lid, the inner vessel, and the ends of the spread ring segment. This seal weld will be visually inspected. The inner vessel will then be evacuated and backfilled with inert gas through a purge port on the inner lid, and the vacuum held for a period of 30 minutes. This cycle is repeated a second time without the 30 minute hold time. Measurements will then be made to ensure there is no inert gas in the region near the inner lid and associated seal welds. An inert gas leak test will then be performed using a suitable detecting device. The purge port will be covered by a purge port cap, which will be welded to the inner lid using a two-pass (minimum) seal weld. This seal weld will be visually inspected and leak tested.

Two outer Alloy 22 lids will be welded to the outer Alloy 22 shell. The first of these, the middle lid, will be placed in the Alloy 22 shell, and a multipass fillet weld will be made between the lid and the Alloy 22 lid. This weld will be inspected using visual and eddy current methods. A second Alloy 22 lid, the outer lid, will be placed in the Alloy 22 shell and joined to the Alloy 22 shell using a multipass, full 


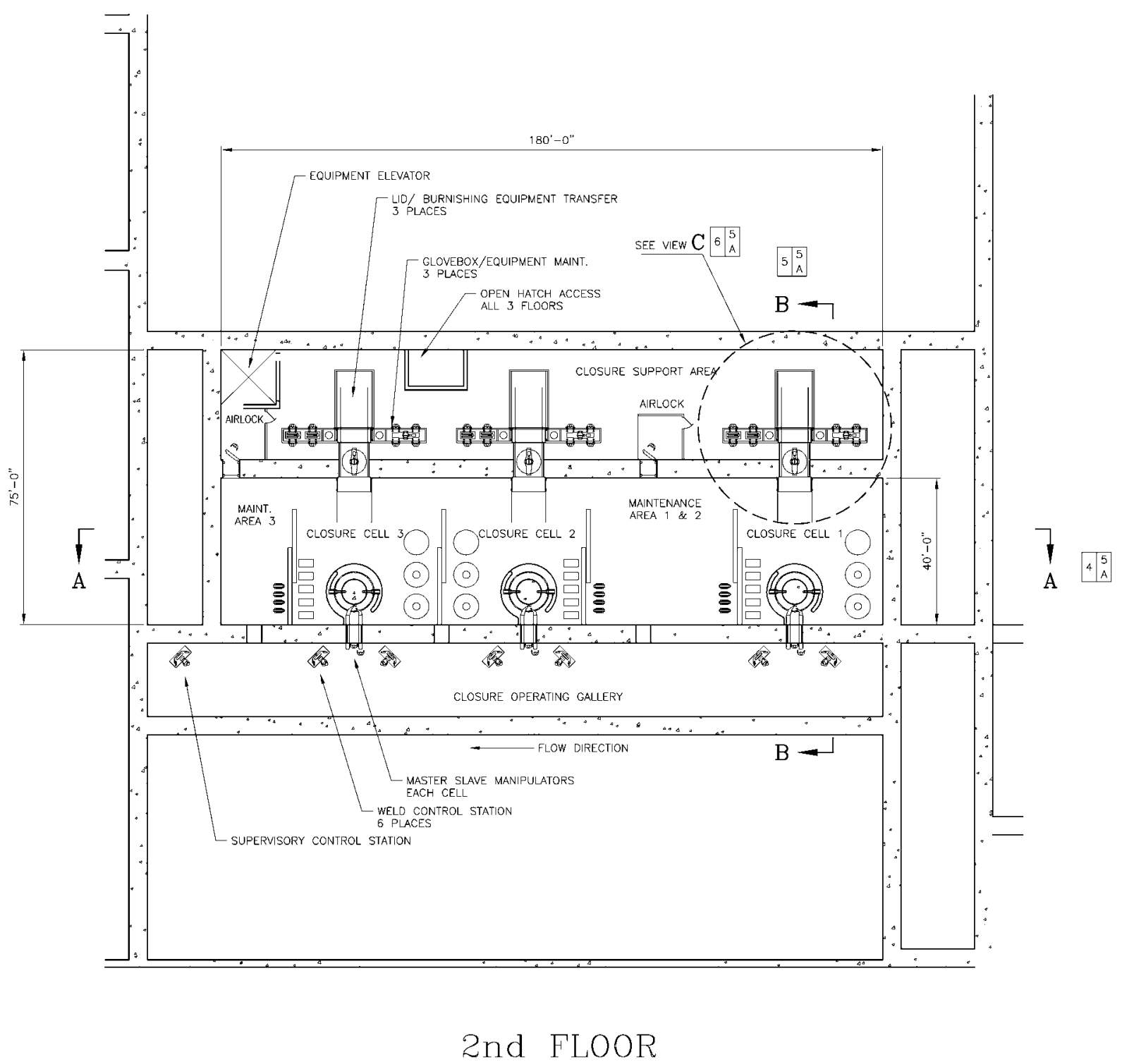

Figure 1. Second floor layout of the closure areas within the Dry Transfer Facility. 


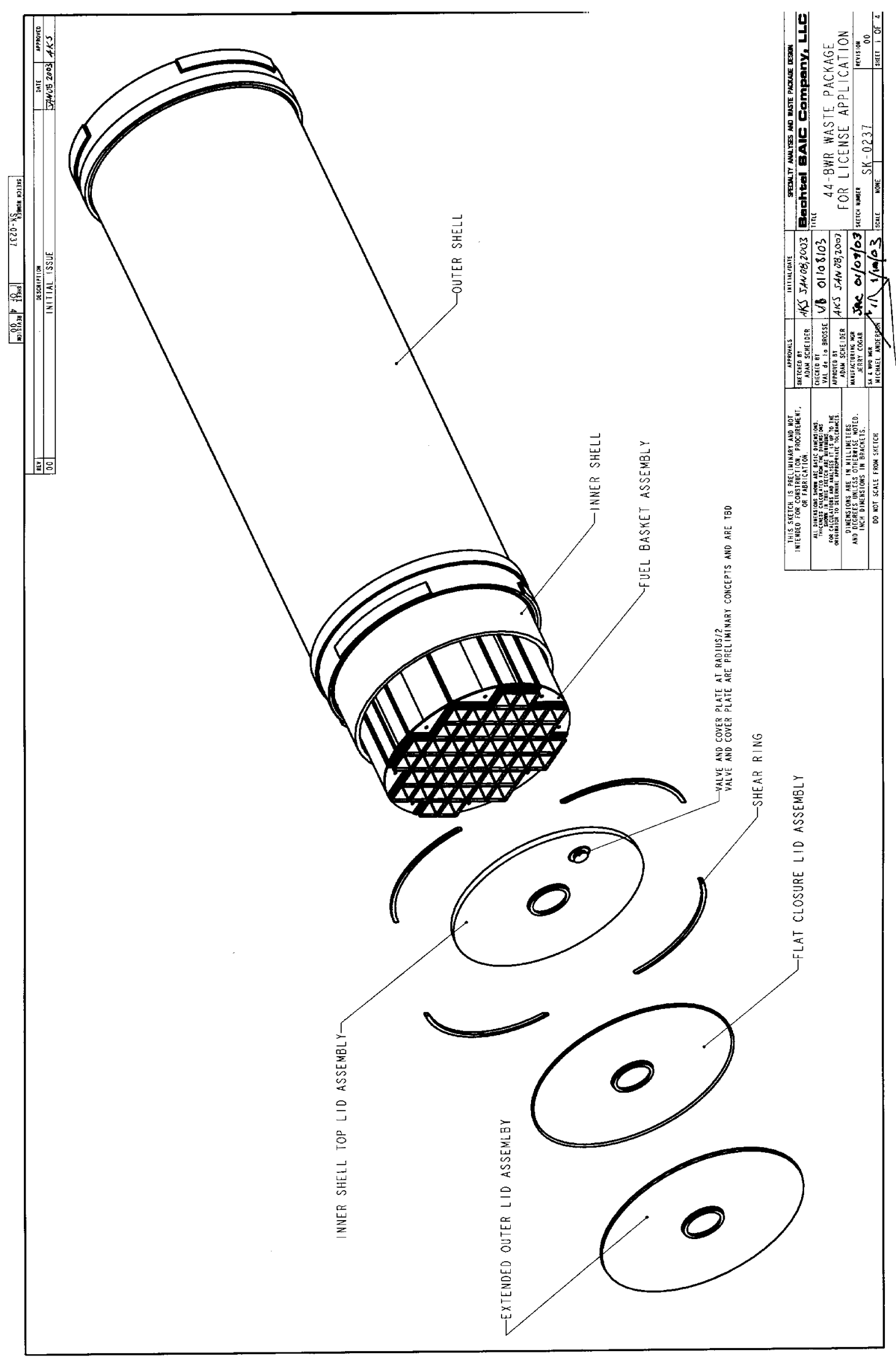

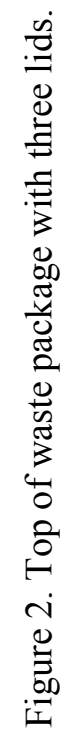


penetration, narrow groove weld. This weld will be inspected using visual, eddy current, and ultrasonic methods. Following inspection, the weld will be stress mitigated by inducing residual compressive stresses in the upper portion of the weld. A second inspection using visual, eddy current, and ultrasonic methods will be performed after the stress mitigation. Figure 3 shows the weld configuration.

The lid welding process includes a number of specific steps and processes. First, the WP and all components of the WP entering the weld cell will be validated to ensure proper identity. The components will then be visually inspected using a video-based method to ensure cleanliness and verify proper positioning. Weld joint area temperatures will be measured by a suitable pyrometric device prior to both tack welding and during welding operations (weld interpass temperatures shall not exceed $350^{\circ} \mathrm{F}$ for the Alloy $316 \mathrm{~L}$ stainless-steel components and $200^{\circ} \mathrm{F}$ for the Alloy 22 components). In the event that components exceed acceptable temperature limits, measures will be used to reduce the temperature below the maximum allowed prior to welding. All components welded to the WP will be visually inspected, and tack welded into position prior to final multipass welding operations. All welds will be performed using the cold-wire, gas tungsten arc welding process (GTAW).

In the event that any of the various inspections reveal a noncompliance condition, reasonable corrective actions may be taken in the closure cell, depending on the condition. If repair of noncompliance conditions is not reasonably possible in the closure cell, the WP will be sent to a designated location outside of the WPCS for additional corrective action.

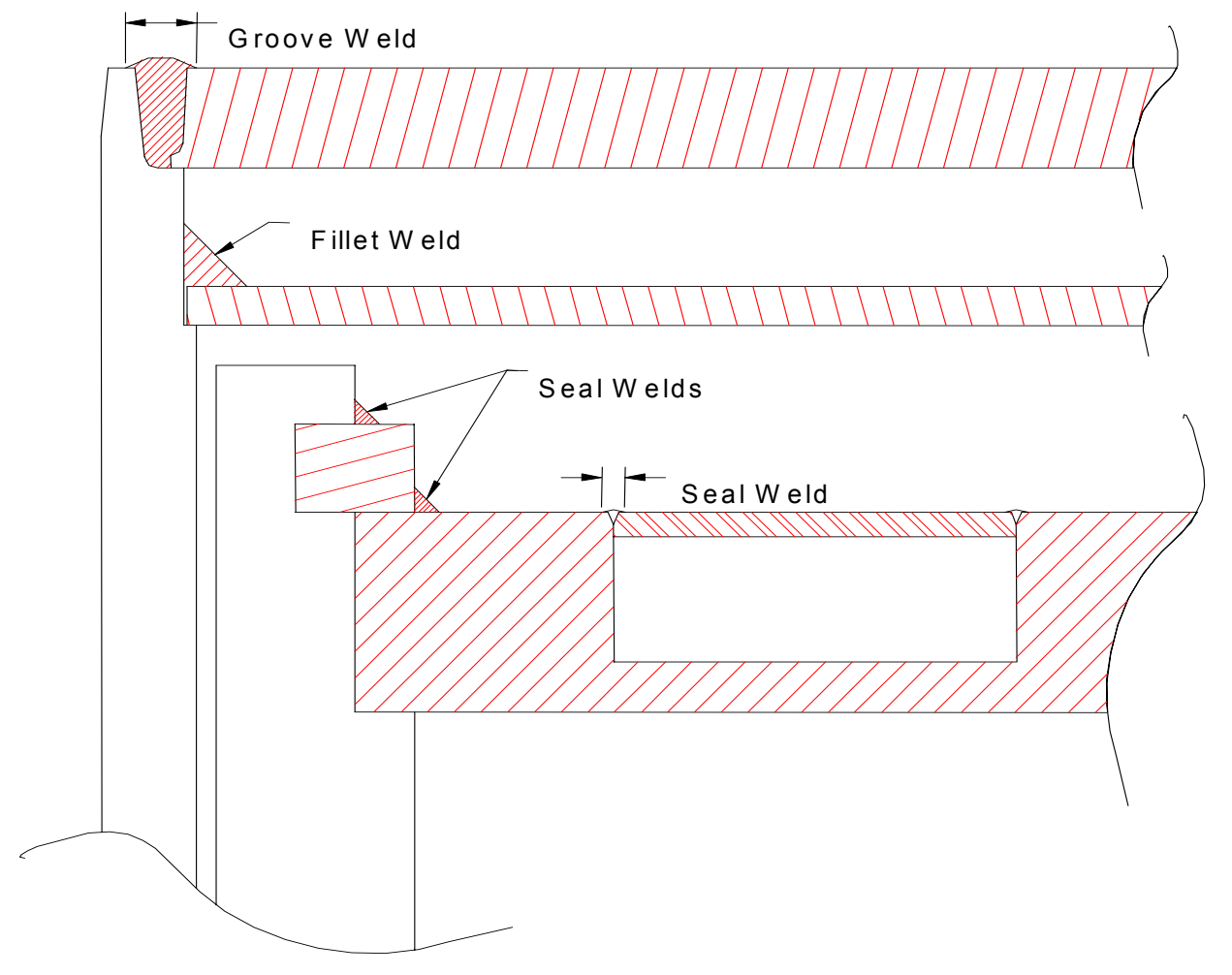

Figure 3. Closure welds for the WP. 


\section{OPERATION AND TECHNICAL REQUIREMENTS}

Two documents have been prepared to identify the requirements associated with the WPCS: "Operation Requirements for the Waste Package Closure System," INEEL/EXT-03-00527 (OR) and "Waste Package Closure System Technical Requirements," INEEL/EXT-03-00728 (TR). Nine functions were identified in OR, which were subsequently mapped to systems with specific technical requirements in the TR. The systems that will require equipment selection are identified in the following sections with a summary of requirements, a preliminary assessment of potential vendors, and a conclusion on development needs (buy, develop, or integrate). Most of the equipment is not particularly specialized in itself, but must withstand high-radiation fields and temperatures. In some cases the equipment items are readily available, but the integrated system is unique and will require a development phase. Integration development needs are also identified.

\subsection{Weld and Inspection System}

\subsubsection{Welding Power Supplies}

Technical Requirements:

Radiation environment: N/A

Rated Output: 450 A/25 V @ 100\% duty cycle (minimum)

Remote contractor control

Remote control of current

Pulse current capability

Input voltage: $460 \mathrm{~V}, 3$-Phase capable

An analog and/or Ethernet interface T-based 100 or 1000

Welding power supply must be able to support cold wire GTAW and direct current electrode negative (DCEN)

Vendors/Capabilities:

- $\quad$ Lincoln Electric: Powerwave 455M

- $\quad$ Domestic supplier

- $\quad$ Meets above criteria

- $\quad$ Has numerous interfaces (e.g. Ethernet, Device Net, and serial port)

- Can also be controlled via analog and digital signals

- $\quad$ Solid state

- $\quad$ Has electrical wave form control 
- $\quad$ Has LabWindows libraries

- $\quad$ Miller Electric: XMT 456 CC/CV and Dimensions 452

- $\quad$ Domestic supplier

- $\quad$ Meets above criteria

- $\quad$ Can also be controlled via analog and digital signals

- $\quad$ Has electrical wave form control

- $\quad$ XMT 456 is an inverter power supply; Dimensions 452 is solid state

- Thermal Dynamics: Power Master 500 and Power Master 500 P

- $\quad$ Domestic supplier

- $\quad$ Both of these power supplies meet criteria

- Both have electrical wave form control

- Can also be controlled via analog and digital signals

- $\quad$ Both are inverters

- $\quad$ PM 500P has pulser in the power supply, the PM 500 does not

- $\quad$ ESAB:

- Internet search

Conclusion:

- $\quad$ No available power supplies that meet our needs

$\boldsymbol{B} \boldsymbol{u} \boldsymbol{y}$ - Welding power supplies commercially exist that will meet our application.

\subsubsection{Welding Torches}

Technical Requirements:

450 A high pulse, 300-350 A average current

No fluids allowed for cooling

Radiation environment: $620 \mathrm{rem} / \mathrm{hr}$ gamma radiation

Remote tungsten change-out capability

$1 / 8$ to $5 / 32$ inch diameter tungsten 
Gases: $100 \% \mathrm{Ar}, 95 \% \mathrm{Ar}-5 \% \mathrm{H} 2$, or $75 \% \mathrm{Ar}-25 \%$ He shielding gas composition. Exact shielding gas composition will be determined at a later date.

Adjustable gas cup

Vendors/Capabilities:

- $\quad$ CK Worldwide Industries:

- $\quad$ Does not have any torches

- $\quad$ Is willing to work with us to develop a torch

- $\quad$ Has sent non-solicited concept drawings

- Does not have engineering analysis capabilities

- Weldcraft:

- $\quad$ Does not have any torches

- Torches with automatic tungsten changers have been used in Japan, but are not sold commercially.

- $\quad$ May address the design but did not seem interested in assigning the development a very high priority.

- $\quad$ Has engineering analysis capabilities

Conclusion:

Develop/Buy - Auxiliary gas cooled welding torches do not exist that will meet this application to be used by INEEL. None appear to have remote change-out capabilities. Torches will be designed and developed by INEEL. Industry will develop the design into a product to be purchased by the INEEL.

\subsubsection{Robotic Welding Arms}

The welding and inspection system for the Yucca Mountain Repository WPCS will employ medium sized, robotic manipulator arms to position the welding, inspection, and repair end effectors to be used in the Closure Cell for remote closure of the Waste Package. This section presents a discussion of robotic manipulator technology, a listing of vendors from whom literature was obtained, and the make/buy decision for acquisition of such robotic manipulators.

Although there are many types of robotic manipulators, probably the most common devices are articulated arm robots, SCARA (Selective Compliance Automatic Robotic Arm) robots, and Cartesian geometry (or gantry) robots. Articulated robotic arms are generally 5 or 6 degree-of-freedom (DOF) devices that roughly mimic the characteristics of a human arm. They are frequently used for arc welding and other industrial applications and are available in many various sizes, capacities and configurations from many manufacturers. SCARA robotics are typically used for precise positioning applications such as placement of electronic components or loading of products into containers. They have a characteristic workspace that is approximately a thick, flat cylinder. There are many small capacity SCARA robots 
available from several manufacturers, and a few large capacity devices available from a limited number of manufacturers. Large capacity SCARA robots typically have a tall base that would make their application to the WPCS awkward at best. SCARA robots have been applied to arc welding applications in limited or no cases. Finally, Cartesian geometry (or gantry) robots are available in both component and fully assembled versions in an extensive range of sizes and capacities. They are frequently used for robotic arc welding and other industrial applications and are available from a large number of manufacturers. This document will only consider articulated arm and Cartesian geometry robots.

Technical requirements:

Two opposing robot arms will be required, 180 degrees apart

Radiation tolerant to a $620 \mathrm{rem} / \mathrm{hr}$ gamma radiation field

Both welding and inspection end effectors will be mounted on the end

Carriages will run concentrically around the circular Waste Package on a rail

Sufficient reach to support welding and inspection of the lid welds on several different diameters of Waste Packages, approximately $1300 \mathrm{~mm}$ combined reach

Sufficient payload to carry the required end effectors, approximately $25 \mathrm{~kg}$

Vendors/capabilities:

Vendors/Capabilities

- $\quad \mathrm{ABB}$

- $\quad$ Adept Technology, Inc.

- $\quad$ Aerotech North America

- American Robot Corporation

- $\quad$ APS Robotics \& Integration

- $\quad$ BMI Automation, Inc.

- Cloos Schweisstechnik

- Denso

- $\quad$ Epson

- $\quad$ Fanuc Robotics

- Hyundai

- Intelligent Actuator

- $\quad$ Kawasaki Robotics (USA), Inc. 
- Lanco AG

- $\quad$ Mitsubishi Electric

- Motoman

- $\quad$ Nachi

- $\quad$ OTC Daihen, Inc.

- $\quad$ Parker Automation

- $\quad$ PaR Systems

- $\quad$ Samsung

- $\quad$ Staubli Unimation

- $\quad$ Seiko

- $\quad$ Thermo CRS, Ltd.

- Yamaha

\section{Articulated arm robots-}

A common characteristic of articulated arm robots is a relatively low payload for a relatively large total robot weight. Consider for example, the data in the following table. The ratio of robot arm weight to payload varies from about 5 to 25 .

\begin{tabular}{|l|l|l|l|l|}
\hline Manufacturer/Robot & Payload & Reach & Robot Weight & Wt/Payload \\
\hline & $\mathrm{kg}$ & $\mathrm{mm}$ & $\mathrm{kg}$ & \\
\hline Denso VM-60B1D & 10 & 800 & 80 & 8 \\
\hline Denso VS-6556E & 5 & 653 & 28 & 5.6 \\
\hline Staubli RX130 & 25 & 1360 & 238 & 9.5 \\
\hline Staubli RX130L & 12 & 1660 & 240 & 20 \\
\hline Motoman SV3X & 3 & 677 & 30 & 10 \\
\hline Motoman UP50 & 50 & 2046 & 550 & 11 \\
\hline Motoman UP20M & 20 & 3106 & 495 & 24.75 \\
\hline Motoman UP20 & 20 & 1658 & 280 & 14 \\
\hline
\end{tabular}




\section{Cartesian geometry robots-}

Cartesian, or gantry robots can typically carry a much larger payload for a given weight of robot. This is shown in the data in the following table for two examples of single-axis Cartesian linear slides. Unlike articulated arm robots, Cartesian robots may be purchased as complete machines or as modules from which one can build custom machines. The two examples shown in the table are modules available for purchase by a machine builder. The ratio of payload to robot weight varies from about 1 to 20 .

\begin{tabular}{|l|l|l|l|l|}
\hline Manufacturer/Robot & Payload & Reach & Robot Weight & Wt/Payload \\
\hline & $\mathrm{kg}$ & $\mathrm{mm}$ & $\mathrm{kg}$ & \\
\hline Parker 412XR & $1470 / 460^{*}$ & 1000 & 71.2 & $0.048 / 0.154^{*}$ \\
\hline Adept R-H module & $80 / 40^{*}$ & 1000 & 35.5 & $0.44 / 0.88^{*}$ \\
\hline
\end{tabular}

*normal/axial

Comments:

The conceptual design for the welding and inspection system for the Yucca Mountain Repository WPCS presents a design based on welding and inspection end effectors mounted on the end of two robot arms each mounted to carriages that run concentrically around the Waste Package on a rail. The robot arms need sufficient reach to support welding and inspection of the lid welds on several different diameters of Waste Packages, and sufficient payload to carry the required end effectors.

A Cartesian robot would seem to be a better choice for the WPCS than an articulated arm robot. However, Cartesian robots do not typically have the type of "wrist" normally found on an articulated robot arm intended for arc welding applications. The multi-axis rotations found on arc welding robots are used to ensure a full range of welding torch manipulations needed for welding. The answer may be to combine the two robot geometries by using a single axis Cartesian robot to position a smaller articulated arm robot.

Conclusion:

Buy - The answer may be to combine the two robot geometries by using a single-axis Cartesian robot to position a smaller articulated arm. Specifications can be prepared for separate systems, then the components can be integrated into a single system specifically for this application.

\subsubsection{Wire Brush}

Technical Requirements:

Radiation environment: $620 \mathrm{rem} / \mathrm{hr}$ gamma radiation field

Operate in a narrow-groove weld profile.

Operate over welds with maximum interpass temperature of $350^{\circ} \mathrm{F}$.

Stainless steel wire 
Vendors/Capabilities:

- Anderson Products:

- $\quad$ Domestic supplier

- $\quad$ Meets above criteria

- Osborn International:

- Domestic supplier

- $\quad$ Meets above criteria

- Weiler Corporation:

- $\quad$ Domestic supplier

- $\quad$ Meets above criteria

Conclusion:

Buy - Wire wheels for this application exist commercially.

\subsubsection{Grinding Wheel}

Technical Requirements:

Radiation environment: $620 \mathrm{rem} / \mathrm{hr}$ gamma radiation field

Operate in a narrow-groove weld profile.

Operate over welds with maximum interpass temperature of $350^{\circ} \mathrm{F}$.

Aluminum oxide composition that is contaminate free (e.g. no iron, sulfur or chlorine)

Vendors/Capabilities:

- Norton Abrasives

- Domestic supplier

- Meets above criteria

Conclusion:

Buy - Grinding wheels for this application exist commercially 


\subsubsection{Grinding Head and Motor}

Technical Requirements:

Radiation environment: $620 \mathrm{rem} / \mathrm{hr}$ gamma radiation field

Ability to use standard abrasive wheel arbors

Operate over welds with maximum interpass temperature of $350^{\circ} \mathrm{F}$.

Vendors/Capabilities:

- RAD Robotic-Accessories:

- $\quad$ Domestic supplier

- $\quad$ Meets above criteria.

- PushCorp, Inc:

- $\quad$ Domestic supplier

- $\quad$ Meets above criteria.

Conclusion:

Buy - Brush motors for this application exist commercially. The mounts may have to be modified to reach the surfaces.

\subsubsection{Wire Feeder}

Technical Requirements:

Radiation environment: $620 \mathrm{rem} / \mathrm{hr}$ gamma radiation field

Remote control capable

Ability to handle wire sizes of 0.035 and 0.045 in. diameter

Wire speed 25-300 inches per minute

Electrical power required is $110 \mathrm{vac}$

Vendors/Capabilities:

- $\quad$ AMET:

- $\quad$ Domestic supplier

- Meets above criteria except radiation resistance 
- Jetline Engineering, Inc.:

- $\quad$ Domestic supplier

- $\quad$ Meets above criteria except radiation resistance

- $\quad$ Cyclomatic/ Jetline Engineering, Inc.:

- $\quad$ Domestic supplier

- $\quad$ Meets above criteria except radiation resistance

Conclusion:

Buy/modify - There are many commercial wire feeders available that would suit this application. However, all of the commercial units would need to be modified to operate in this radiation environment.

\subsubsection{Wire Guide Positioners}

Technical Requirements:

Radiation environment: $620 \mathrm{rem} / \mathrm{hr}$ gamma radiation field

Two degrees of freedom

Remote control capability

Operate over welds with maximum interpass temperature of $350^{\circ} \mathrm{F}$.

Wire guide adjustments to be 2 -axis, horizontal and vertical, \pm 0.25 in. each

Vendors/Capabilities:

- AMET:

- Domestic supplier

- $\quad$ Meets above criteria except size

- Jetline Engineering, Inc.:

- $\quad$ Domestic supplier

- $\quad$ Meets above criteria except size

- Panasonic:

- $\quad$ Domestic supplier

- $\quad$ Custom orders

- $\quad$ Meets above criteria except size 
Conclusion:

Make - Commercial wire positioners are available, however these units are fairly large in size and weight. The INEEL has built and used a smaller 2 axis wire positioner on current systems.

\subsubsection{Wire Cutting Station}

Technical Requirements:

Radiation environment: $620 \mathrm{rem} / \mathrm{hr}$ gamma radiation field

Ability to cut filler wire close to wire guide positioner.

Ability to cut wire sizes 0.035 in. to 0.045 in. diameter.

Remote control capability

Vendors/Capabilities:

- $\quad$ Alexander Binzel Corporation:

- $\quad$ Foreign supplier

- $\quad$ Meets above criteria

- Thermadyne:

- Domestic supplier

- $\quad$ Meets above criteria

- Tregaskis:

- $\quad$ Foreign supplier

- $\quad$ Meets above criteria

Conclusion:

Buy - Commercial wire cutters were used on the GMAW robotic application. The stock commercial unit may have to be modified to the required configuration.

\subsubsection{Arc Viewing Camera System}

Technical Requirements:

Radiation environment: $620 \mathrm{rem} / \mathrm{hr}$ gamma radiation field.

Last 60 hours of operation within specified radiation field.

Provide clear view of welding pool and joint area. 
Operate over welds with a maximum interpass temperature of $350^{\circ} \mathrm{F}$.

110 Vac input power.

Cameras be CMOS and $30 \mathrm{~Hz}$.

Vendors/Capabilities:

- $\quad$ AMI Arc Machines, Inc.: "Direct Arc View Color Video System"

- $\quad$ Domestic supplier

- $\quad$ AMI offers a high quality image system. Their company has a good reputation in the welding industry. The system is a CCD based camera system with auto switching between viewing modes, and AMI does custom designs as part of daily business.

- $\quad$ Jetline Engineering, Inc.: "JetView"

- $\quad$ Domestic supplier

- Jetline offers a quality image system utilizing a simple arc suppression scheme. They are a reputable company in the welding industry. Their system is a CCD based camera system with manual switching between viewing modes. Jetline does not generally do custom designs far from their base system on arc viewing systems.

- $\quad$ Control Vision, Inc.: "WeldingCam"

- $\quad$ Domestic supplier

- $\quad$ Control Vision supplies a quality image system based on current technology. Their system is a CCD based camera system with the option to run it in an automatic switching mode. They do custom designs frequently, and their company is very small, only based on camera systems.

- $\quad$ Symphotic TII Corp: "MegRAD 1"

- $\quad$ Domestic supplier

- $\quad$ Symphotic offers a radiation hardened camera system that can operate in the radiation fields. The system is not an arc viewing camera system but it may be possible to combine this camera with another manufactures arc viewing technology to provide a radiation hardened arc viewing camera system.

Comments:

All of the arc-viewing camera systems surveyed provides images suitable for remote welding.

None of the arc viewing camera systems is currently radiation hardened although AMI and Control Vision seem very willing to work on designs specific for our application. 
None of the camera systems off the shelf will handle the high temperatures associated with our welding application; all systems could be modified to provide sufficient cooling.

Conclusion:

Buy - The recommendation is to contract with one of the above arc viewing camera manufacturing companies to build a camera system based on their existing design that would implement the MegRAD 1 camera providing the radiation tolerance required. The custom design would also be required to provide cooling to meet the high temperature requirements.

\subsubsection{Seam Tracking/Quantitative Visual Topography Inspection}

Technical Requirements:

Provide for seam tracking and weld profile measurements in a single package.

Radiation environment: $620 \mathrm{rem} / \mathrm{hr}$ gamma radiation field.

Last a minimum of 60 hours of operation within specified radiation field.

Operate over welds with a maximum interpass temperature of $350^{\circ} \mathrm{F}$.

Distinguish defect with a magnitude of $1 / 32$ inch.

2-3 Hz update rates for 10 ipm seam tracking.

Operate with a cold wire feed tungsten inert gas welding system utilizing camera systems both in front and behind the weld torch.

$110 \mathrm{VAC}$ input power.

Vendors/Capabilities:

- $\quad$ Servo Robot:

- $\quad$ Foreign supplier (Domestic office, Foreign built in Canada)

- $\quad$ This company builds a large line of products for laser based seam tracking and inspection. They seem to be the leader in the field in technology and have the widest array of products. Their hardware utilizes CMOS based imagers which are much more radiation tolerant than the more common CCD imagers. They do not build a single system to do both seam tracking and weld profiles, but they could easily combine two of their off the shelf systems into a single package that will provide the needed functionality.

- Jetline Engineering, Inc.:

- $\quad$ Domestic supplier

- $\quad$ This company builds a wide range of welding hardware. They offer both a tactile and optical seam tracking system. Neither system appears well tailored to the application and they do not provide any ability of doing weld profile measurements. 
- $\quad$ Meta Vision Systems:

- $\quad$ Foreign supplier (Canada)

- This company builds a laser CCD camera seam tracking system. They do not have any standard off the shelf systems for weld bead profile measuring, but have done several custom systems. They state they could combine their seam tracking system with one of their previously design weld profile systems to provide a package to meet the requirements. Technically this system would meet our needs, but it is based on a CCD camera that is inherently not radiation tolerant.

- Q-Tec Engineering:

- $\quad$ Foreign supplier (Canada)

- This company builds a unique circular laser CCD camera based seam tracking system. The circular scan not only provides the ability to track the joint laterally but also provides the direction of the joint. While this functionality is unique to this sensor package, it is not needed for our application. The increased complexity of the circular scanning laser that provides no increased value to this application makes this system unattractive for this project. The system is also based on a CCD camera that is inherently not radiation tolerant.

Conclusion:

Buy - The recommendation is to purchase a system based on currently off the shelf hardware, which is customized to meet the specific application.

\subsubsection{Eddy Current (ET) Inspection Equipment}

Technical Requirements:

Provide inspection of weld surfaces

Operates over welds with a maximum surface temperature: $350^{\circ} \mathrm{F}$

Radiation environment: $423 \mathrm{R} / \mathrm{hr}$

Must be able to inspect fillet, repair cavity, and final weld surfaces

Remote operation

Evaluation software to established flaw criteria of $\geq 1 / 16$ in.

$2-3 \mathrm{~Hz}$ update rates during inspection 
Vendors/Capabilities:

- $\quad$ Agfa NDT, Inc.:

- $\quad$ Foreign Vendor

- $\quad$ Supplies multi-frequency systems, but have limited support for multiple probes

- Serial interface for communication

- $\quad$ No array equipment

- $\quad$ Provides conventional and custom inspection probes, development will be required

- $\quad$ No computer evaluation software

- Jentek Sensors, Inc.:

- Domestic Vendor

- $\quad$ Supplies a multi-frequency system

- Use meandering coil technique with quantitative inversion computer algorithm

- Coils are placed on kapton, which is moldable into the weld repair cavity

- $\quad$ Probe to control box is 15 to $30 \mathrm{ft}$, from control box to computer is $100 \mathrm{ft}$

- $\quad$ Probe development is required to address weld configurations

- $\quad$ No computer evaluation software

- Quality Network, Inc

- $\quad$ Foreign Vendor

- $\quad$ Grouped personal computer boards, up to 64 channels, all functions controlled via software

- $\quad$ Complete executable software or $\mathrm{C}++$ available, no LabView@ (for board operation)

- $\quad$ Has built in probes (little information available) can use almost any available probe, but will require development

- $\quad$ Sensor-to-equipment distance: $15 \mathrm{ft}$

- $\quad$ Not advertised as an array system; however, with software development it could provide array capability

- No computer evaluation software 
- $\quad$ RD-Tech:

- $\quad$ Foreign Vendor

- $\quad$ MS 5800, multifrequency system, supports array or multiple channel probe scanning

- $\quad$ Stand-alone system, various communication ports to system computer

- $\quad$ Test frequency $20 \mathrm{~Hz}$ to $6 \mathrm{MHz}$

- $\quad$ System communicates to acquisition computer system using a 100Base-T Fast Ethernet

- $\quad$ Some thresholding analysis software available, offer software development kit

- Offer special moldable probes for repair cavities, also offer array probes that are 10 to 40 times faster than a rastered single probe.

- $\quad$ Canadian owned, have US representatives and facilities

- $\quad$ Development and integration work will have to be done

- $\quad$ Staveley NDT Technologies:

- $\quad$ Domestic Vendor

- $\quad$ Power station can support up to 4 probes, $100 \mathrm{~Hz}$ to $12 \mathrm{MHz}$

- $\quad$ System controlled via serial line, eddy current output is analog

- $\quad$ Instrument-to-probe distance is $25 \mathrm{ft}$.

- $\quad$ Development, and integration work will have to be done

- $\quad$ Some question on probe ability to withstand radiation fluxes

- $\quad$ ZETEC, Inc.:

- $\quad$ Domestic Vendor

- $\quad$ Multifrequency system that can support up to 40 probes

- $\quad$ System communicates to acquisition computer system using a 100Base-T Fast Ethernet

- $\quad$ Offer conventional as well as customs probes

Conclusion:

Buy/develop/integrate - Equipment exists to meet some of the application needs for the eddy current system; however, integration and probe development will be required. 


\subsubsection{Ultrasonic Nondestructive Examination Equipment}

Technical Requirements:

Post and in-process inspection required

Surface temperature: $200^{\circ} \mathrm{F}$

Either uses no couplant or limited amounts of deionized water. The amount is TBD.

Radiation environment: $160 \mathrm{R} / \mathrm{hr}$

Inspection speeds $=8 \mathrm{ipm}$, minimum

Vendors/Capabilities:

- $\quad$ Table 1 contains a summary of the vendor survey. NIC testing is a mature technology with commercial vendors supplying a broad range of transducers, instrumentation, and integrated systems. However, for this application, the stated requirements stretch or exceed the technical capabilities of the existing technologies.

Surface Temperature: $200^{\circ} \mathrm{F}$ (transients up to $930^{\circ} \mathrm{F}$ ) - High temperature transducers exist that can tolerate the $200-930^{\circ} \mathrm{F}$ environment. These transducers typically require high temperature couplants and intermittent contact. Noncontacting transducers such as Electromagnetic acoustic transducers (EMATS) are better suited for continuous high temperature testing. They require no couplant and can be built to work continuously at $700^{\circ} \mathrm{F}$ with transients to $1,300^{\circ} \mathrm{F}$. Unfortunately, EMATS suffer from low transmitted ultrasonic energy thereby resulting in low signal to noise ratios.

- No couplant - Conventional ultrasonic techniques use water or a similar liquid/gel material to mechanically couple the ultrasonic energy into the test sample. Obviously, the use of liquid couplant is not always viable and techniques have been developed to limit or remove the need for couplant. Those techniques include dry coupling, electromagnetics, and lasers. Dry coupling depends on soft elastomers and pressure to couple the transducer to the test piece. The limitations of this approach are that the elastomers significantly attenuate the ultrasonic energy yielding low signal to noise ratios and are susceptible to both heat and radiation. Electromagnetic techniques use magnetic fields to excite and detect the sound. This approach is noncontacting and is well suited for elevated temperature testing, but due to limited coupling, suffers from low ultrasonic energy transmission. Laser techniques use high-energy laser pulses to produce ultrasound and interferometric techniques to detect the surface vibrations of the return signals. Laser based technologies are less developed than the other techniques and suffer from low detection efficiency, sensitivity to surface conditions, and complexity. It is also more difficult to control beam focusing and directionality.

- $\quad$ Radiation environment: $160 \mathrm{R} / \mathrm{hr}$ - Ultrasonic techniques have been successfully used in radiation environments but test times have been short. As a result, the long-term durability of the transducers and associated cabling in high radiation fields is not known.

- $\quad$ Welding speeds $=8 \mathrm{ipm} / G T A W$ - Inspection rates are more than adequate to address an 8 ipm welding speed. 
Table 1. Vendors Surveyed.

\begin{tabular}{|c|c|c|c|c|c|c|c|c|}
\hline Vendors & 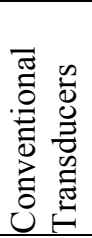 & 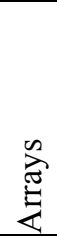 & 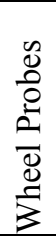 & $\sum_{1}^{E}$ & 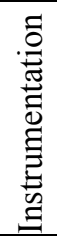 & 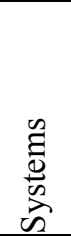 & 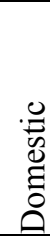 & Comments \\
\hline Dapco Industries Inc. & $\mathrm{X}$ & & $\mathrm{X}$ & & & $\mathrm{X}$ & $\mathrm{X}$ & $\begin{array}{l}\text { Supplies transducers and specialized systems; } \\
\text { wheel probes requires couplant to function }\end{array}$ \\
\hline AGFA - KrautKramer & $\mathrm{X}$ & $\mathrm{X}$ & & & $\mathrm{X}$ & $\mathrm{X}$ & & Supplies phased array transducers and systems \\
\hline GE - Panametrics & $\mathrm{X}$ & & & $\mathrm{X}$ & $\mathrm{X}$ & $\mathrm{X}$ & $\mathrm{X}$ & $\begin{array}{l}\text { Supplies conventional transducers and } \\
\text { instrumentation }\end{array}$ \\
\hline RD-Tech & $\mathrm{X}$ & $\mathrm{X}$ & & $\mathrm{X}$ & $\mathrm{X}$ & $\mathrm{X}$ & & $\begin{array}{l}\text { Supplies phased array transducers and systems; } \\
\text { water wedge technology }\end{array}$ \\
\hline Sigma Transducers & $\mathrm{X}$ & $\mathrm{X}$ & $\mathrm{X}$ & & & & $\mathrm{X}$ & $\begin{array}{l}\text { Supplies conventional transducers, dry coupled } \\
\text { wheel probes, and flexible arrays }\end{array}$ \\
\hline Sonatest Inc. & $\mathrm{X}$ & & $\mathrm{X}$ & & $\mathrm{X}$ & & & $\begin{array}{l}\text { Supplies conventional transducers and dry } \\
\text { coupled wheel probes; wheel probes cannot } \\
\text { tolerate } 200^{\circ} \mathrm{F}\end{array}$ \\
\hline Staveley NDT Technologies & $\mathrm{X}$ & & $\mathrm{X}$ & & $\mathrm{X}$ & $\mathrm{X}$ & $\mathrm{X}$ & $\begin{array}{l}\text { Supplies conventional transducers, dry coupled } \\
\text { wheel probes, and field systems; wheel probes } \\
\text { cannot tolerate } 200^{\circ} \mathrm{F}\end{array}$ \\
\hline NDT International & $\mathrm{X}$ & & $\mathrm{X}$ & & $\mathrm{X}$ & $\mathrm{X}$ & $\mathrm{X}$ & $\begin{array}{l}\text { Supplies conventional transducers, dry coupled } \\
\text { wheel probes, and handheld field systems }\end{array}$ \\
\hline Sonix & & & & & $\mathrm{X}$ & $\mathrm{X}$ & $\mathrm{X}$ & Supplies scanning systems and software \\
\hline $\begin{array}{l}\text { UTEX Scientific Instruments } \\
\text { Inc. }\end{array}$ & & & & & $\mathrm{X}$ & & & $\begin{array}{l}\text { Supplies system components and scanning } \\
\text { software }\end{array}$ \\
\hline Harfang Microtechniques Inc & & & & & & $\mathrm{X}$ & & Supplies handheld phased array system \\
\hline Imasonic & $\mathrm{X}$ & $\mathrm{X}$ & & & & & & $\begin{array}{l}\text { Supplies conventional and phased array } \\
\text { transducers }\end{array}$ \\
\hline EMAT Ultrasonics Inc & & & & $\mathrm{X}$ & & $\mathrm{X}$ & $\mathrm{X}$ & Supplies EMATS and systems \\
\hline Innerspec Technologies Inc. & & & & $\mathrm{X}$ & & $\mathrm{X}$ & $\mathrm{X}$ & Supplies EMATS and systems \\
\hline $\begin{array}{l}\text { Matec Instruments Companies } \\
\text { Inc }\end{array}$ & & & & & $\mathrm{X}$ & $\mathrm{X}$ & $\mathrm{X}$ & $\begin{array}{l}\text { Supplies high power systems for conventional } \\
\text { ultrasonics and EMATS }\end{array}$ \\
\hline Ritec Inc. & & & & & $\mathrm{X}$ & $\mathrm{X}$ & $\mathrm{X}$ & $\begin{array}{l}\text { Supplies high power systems for conventional } \\
\text { ultrasonics and EMATS }\end{array}$ \\
\hline
\end{tabular}

Conclusion:

Buy - Instrumentation and systems exist to meet the basic requirements.

Develop/Make - Although systems and scanning software exist, work will need to be performed to integrate/interface the systems and software with the robotics and process control system.

Develop/Make - Transducers/transducer assemblies are not commercially available to fully address the lack of coupling, temperature and radiation fields. Work will need to be performed to develop and test appropriate sensors. It will also be necessary to design transducer configurations to match the specific test geometry for this application. 


\subsection{Inert and Leak Detection}

\subsubsection{Inert Backfill Equipment}

Technical Requirements:

Vacuum equipment shall be capable of pulling a vacuum of at least 3 Torr.

The volume to be evacuated is 7.1 cubic meters.

Temperature of gas being evacuated is $200^{\circ} \mathrm{F}$.

Gas being evacuated may be either air or helium.

Air could potentially be "wet". If filter system is used, must be remotely maintained.

Evacuation time shall not exceed 15 minutes.

Vendors/Capabilities:

- A-Vac Industries:

- $\quad$ Provide a multitude of vacuums and accessories

- $\quad$ Meets above criteria

- $\quad$ Pneumotech, Inc.:

- $\quad$ Provide a multitude of vacuums and accessories

- $\quad$ Meets above criteria

- $\quad$ Becker Vacuum Technology

- $\quad$ Provide a multitude of vacuums and accessories

- $\quad$ Meets above criteria

Conclusions:

Buy/Develop - Basic vessel evacuating equipment is readily available. These components include the vacuum system, filters, heat exchangers, and moisture removal equipment. The purge nozzle that interfaces with the waste package lid will be fabricated in house to conform with radiation and sealing requirements.

\subsubsection{Leak Detection Equipment}

Technical Requirements:

Radiation environment: $620 \mathrm{R} / \mathrm{hr}$ gamma radiation field 
Equipment shall be capable of performing leak tests on the following waste package diameters:
(1) $65.1 \mathrm{in}$
(2) 66.3 in.
(3) 52.3 in.
(4) $52.8 \mathrm{in}$.
(5) 83.5 in.
(6) $77.1 \mathrm{in}$.
(7) 71.8 in.

It is preferred although not required that a single piece of equipment be capable of performing the leak tests on all packages.

Equipment shall be capable of measuring Helium leak rates down to $10 \mathrm{E}-6 \mathrm{~cm}^{3} / \mathrm{sec}$ on both the inner lid seal welds and the purge cap weld.

Gases removed during the leak testing shall be filtered using a HEPA filtering System.

The seal weld on the purge port shall be helium leak tested to verify leak rates less than $10 \mathrm{E}-3 \mathrm{~cm} 3 / \mathrm{sec}$.

Leaks detected in either the inner lid seal or the purge cap seal shall be identified and located. Vendors/Capabilities:

- $\quad$ A-Vac Industries:

- $\quad$ Vendor of mass spectrometers and hand held sniffers.

- $\quad$ Able to provide leak detector accessories.

- $\quad$ Do not provide testing apparatus.

- $\quad$ Cincinnati Test Systems, Inc.:

- $\quad$ Supplies similar equipment to other industries

- $\quad$ Never done anything this size

- $\quad$ Never worked in radiation environment

- $\quad$ Helium Leak Testing, Inc.:

- $\quad$ Have experience building leak detection equipment for large vessels

- $\quad$ Provide turn key systems 
- $\quad$ Never worked in a high radiation environment

Comments:

Of the companies contacted, Helium Leak Testing Inc. was the most experienced. They can meet all the criteria with the exception of having had experience in a high radiation environment.

Conclusions:

Buy/Develop - It is likely that we will employ the expertise of Helium Leak Testing Inc. in building the leak detection test ring. The rest of the required components will be purchased and integrated.

\subsection{Control and Data Management}

\subsubsection{Control and Data Management Software}

Technical Requirements:

Software shall operate on a personal computer platform.

Software shall operate under a Microsoft windows environment.

Software shall provide Video support (a video window)

Development support shall be provided.

Software shall have graphical trend capability.

Software shall allow multiple (minimum of three) process variables on a trend graph.

Software shall have a comprehensive image library containing common process images.

Software shall allow the use of images from outside sources.

A user programming control language shall be provided.

Database interfacing for data archival shall be provided.

Report generation capability shall be provided.

Software shall operate in a client server environment.

Software shall provide low-level motion control support.

Software shall provide for Ethernet Transmission Control Protocol/Internet Protocol (TCP/IP) communications.

Software shall provide security control.

Vendors/Capabilities: 
- National Instruments - Lab View:

- $\quad$ Meets all the technical requirements.

- Wonderware

- $\quad$ Does not provide the low-level motion control.

- $\quad$ Excellent product support and graphical capabilities.

- $\quad$ Rockwell's RSView

- $\quad$ Does not provide low-level motion control. Relies on PLC control to provide motion.

- $\quad$ Licensing fees excessive.

- Iconics

- $\quad$ Only Provides a Visual Basic symbol library.

- $\quad$ Does not provide video support or low-level control.

Conclusions:

Buy - Several vendors meet our basic requirements. These will be evaluated to determine which best fits our needs and provides the project with the most value. The selected product will then be purchased and used to develop the system control and data acquisition software.

\subsubsection{Control and Data Management Operator Station}

Technical Requirements:

The stations shall be designed to be ergonomically condusive to operator function.

Each station shall contain a pc-based computer system running the latest Windows ${ }^{\mathrm{TM}}$ Operating System.

Each station shall have a UPS for limited backup power (provide power long enough to do a safe shutdown in the event of facility power failure).

Each station shall be comprised of at least three video monitors and two computer monitors (at least one computer monitor will have touch screen input capability).

Each station shall have data storage capability compatible with the amount of archival data collected during the closure operation for one WP.

A joystick shall be provided at stations requiring tele-operative control of closure cell devices.

Each station shall be networked via Ethernet (TCP/IP). 
Vendors/Capabilities:

- $\quad$ Agile Engineering:

- $\quad$ Domestic vendor

- $\quad$ Provides monitoring and ergonomic equipment

- $\quad$ Commercially available product

- Successful history in deployment of compact remote consoles

- $\quad$ Product was developed under DOE funding

- Dell Computer Corporation:

- Domestic vendor

- $\quad$ Excellent maintenance support

- Well established to provide long term service

- Wide selection of computers that meet the requirements

- Opti-UPS Corporation:

- $\quad$ Domestic vendor

- $\quad$ Variety of products to meet changing requirements

- $\quad$ Proven reliable through past experience

- $\quad$ CyberResearch, Inc.:

- $\quad$ Domestic Vendor

- Well established to provide long term service

- Distributes a variety of monitors that meet the requirements

- $\quad$ Advantech Company:

- $\quad$ Domestic Vendor

- $\quad$ Provides compact, wall mounted systems that meet the requirements for glovebox operator stations.

Conclusions:

Buy/Integrate - Many vendors are available to provide the components of the operator work stations/control stations. INEEL will integrate parts from vendors to configure and build the workstations. Dell computers are easily obtained by INEEL for the prototype. Dell is the first choice in 
computer manufacturers. Sanyo and NEC manufacture high-resolution displays and NEC is considered the best based on the following:

- NEC has the widest view angel on the market of 170 degrees.

- NEC brightness values exceed $300 \mathrm{~cd} / \mathrm{m} 2$.

- NEC has multiple electronic interface connections providing compatibility with many systems.

- NEC has LCD displays as large as 40".

- Large displays are LCD not TFT technology. This eliminates the "burn-in" effect associated with displays containing phosphorus.

INEEL will base the design on guidance from human factors for the best ergonomic design.

\subsubsection{Waste Package Identification System}

Technical Requirements:

Each WP and associated component (inner lid, spread ring, middle lid, and outer lid) will be labeled with an identifying code previous to entering the closure cell that can be read visually and by electronic means.

Lighting will be provided that will highlight the identifying code for electronic reading.

All identifying codes will be placed on the components so they can be read from above the WP.

An index mark will be provided on the WP along with the identifying code which will be used as a reference for all data tracking of the welding and inspection operations.

Vendors/Capabilities:

- Cognex Corporation

- Domestic vendor

- $\quad$ Machine vision component supplier

- $\quad$ Leader in the machine vision arena

- $\quad$ Good support structure

- $\quad$ Cohu Inc., Electronics Division

- Domestic vendor

- $\quad$ Cameras are made and manufactured in the USA

- $\quad$ Rad-hardened cameras available as well as CMOS cameras

- Well known for their engineering capabilities

- $\quad$ Very good maintenance support 
- $\quad$ Region of Interest scanning for reduced data requirements

- $\quad$ High resolution cameras available at a reasonable price

- $\quad$ Manufacture shielded camera enclosures for high rad areas

- $\quad$ EPIX, Inc.

- $\quad$ Domestic vendor

- $\quad$ Manufactures high-end frame grabber boards for digital video processing

- $\quad$ Compatible with a variety of manufacturers' cameras

- Well established in the vision industry

- $\quad$ Pulnix America, Inc.

- Domestic branch

- Manufacturers a variety of CMOS and CCD cameras for machine vision applications

- $\quad$ Automated Concepts, Inc.

- $\quad$ Domestic vendor

- Machine vision/robotics integrator

- $\quad$ RVSI Acuity CiMatrix

- $\quad$ Domestic vendor

- $\quad$ 2-D barcode reading and marking capability

- Powermation

- $\quad$ Domestic vendor

- $\quad$ 2-D barcode reading capability.

Conclusions:

Buy/Integrate - Several of the vendors described market products that could be used to read the component ID of the WP. Testing and additional research is needed to determine the affects of radiation on the products. The requirement of reading all ID markings from above the WP needs to be addressed relative to these vendors and their products. 


\subsection{Material Transfer and Maintenance Support}

\subsubsection{Closure Cell Remote Video (CCRV)}

Technical Requirements:

Color viewing with pan, tilt, and zoom magnification of TBDX.

Radiation environment: up to $620 \mathrm{rem} / \mathrm{hr}$ gamma radiation field

Glass-less stereo 3-D camera systems

All equipment, controls, interfaces, wiring, and supports are an engineered, integrated system

Modular and remotely replaceable

Supplementary lighting included

Decontaminatable using a spray wash of water, nitric acid, and other standard decontamination solutions.

Domestic manufacturer with a history of production of similar equipment preferable

Vendors/Capabilities:

- $\quad$ R. J. Electronics: Salem, OR

- $\quad$ Domestic vendor

- $\quad$ Meets above criteria for standard 2-D systems

- $\quad$ Extensive experience in nuclear and underwater industries

- $\quad$ Specialized in remote operation and hazardous environments

- $\quad$ Successful history of equipment at INEEL, Hanford, and other DOE sites

- $\quad$ Dimension Technologies: (DTI), Rochester, N.Y.

- Domestic manufacture

- $\quad$ Meets above criteria for 3-D systems

- $\quad$ Extensive experience in space and aerospace industry

- $\quad$ Specialized in remote operation and hazardous environments

- $\quad$ Successful history of equipment at INEEL, Hanford, and other DOE sites

Conclusion:

Buy - A system that meets the requirements exits commercially. 
Overhead Closure Cell Crane

Technical Requirements (General):

Bridge mounted system that provides motion in $\mathrm{x}, \mathrm{y}$, and $\mathrm{z}$ axes,

Designed per Crane Manufacturers Association of America (CMAA)-70.

Z-axis shall be wire rope hoists with TBD-ton/5-ton hook combination,

Remote rotation of 5-ton hook shall be provided,

Seismic restraints during UBC Seismic Event

Load limiting available on all hoists

Sealed lubricated irradiation tolerant bearing

Each axis of motion shall include position feedback information.

Radiation resistant to $10^{8} \mathrm{Rad}$ accumulated dose,

Ability to be decontaminated by spray washing with water, nitric acid, and other standard decontamination fluids

Redundancy of active components for fail-safe operation and retrieval from remote locations

Local and remote control stations

Remotely maintainable

460 volt, 3 phase $60 \mathrm{~Hz}$ power system

Variable speed hoist

Electrically released nail breaks on each axis

Remotely controllable and local pendant control

Optional ethernet/TCP/IP connections

Bridge-to-rail and trolley-to-rail restraining devices that are remotely retractable

Domestic manufacture with 5-year minimum history of production of similar equipment preferred Vendors/Capabilities:

- $\quad$ American Crane and Equipment Company: (ACECO)

- Domestic manufacture

- $\quad$ Meets above criteria 
- $\quad$ Extensive experience in nuclear and aerospace industries

- $\quad$ Specialized in remote operation and hazardous environments

- $\quad$ Successful history of equipment at INEEL, Hanford, and other DOE sites

- $\quad$ NQA-1 and NOG-1 certified crane vendor

\section{- $\quad$ Ederer Cranes:}

- $\quad$ Domestic manufacture

- $\quad$ Meets above criteria

- $\quad$ Extensive experience in nuclear industry

- $\quad$ Specialized in remote operation and hazardous environments

- $\quad$ Successful history of equipment at INEEL, Hanford, and other DOE sites

- $\quad$ NQA-1 and NOG-1 certified crane vendor

Conclusion:

Buy - ACECO and Ederer are the primary industry competitors when dealing with cranes in hazardous environments. They have both focused on the nuclear industry and have both built quality assurance programs that support the majority of specifications that are written. Their track records are both very impressive.

\subsubsection{Overhead Closure Support Area Crane}

Technical Requirements:

Bridge mounted system that provides motion in $\mathrm{x}, \mathrm{y}$, and $\mathrm{z}$ axes,Designed per CMAA-70.

Sealed lubricated bearing that are radiation tolerant and have a minimum design life of TBD years

Z-axis shall be wire rope hoist with a hook

Remote rotation of hook available

Load limiting available on hoist technology

Each axis of motion shall include position feedback information.

Ability to be decontaminated by spray washing with water, nitric acid, and other standard decontamination fluids

Local pendant control available

Optional ethernet/TCP/IP connections 
Bridge-to-rail and trolley-to-rail restraining devices that are retractable

Variable speed hoist motors each equipped with electrically release rail-safe brakes

Controlled via a mobile and detachable control module, capable of controlling all crane motions with the module designed to plug into multiple flush-mounted control station with receptacles located near the shield windows

460-volt, 3-phase 3-wire (plus ground) and $60 \mathrm{~Hz}$ power sources

Domestic manufacture with 5-year minimum history of production of similar equipment preferable Vendors/Capabilities:

- $\quad$ American Crane and Equipment Company: (ACECO)

- Domestic manufacture

- Meets above criteria

- $\quad$ Extensive experience in nuclear and aerospace industries

- $\quad$ Specialized in remote operation and hazardous environments

- $\quad$ Successful history of equipment at INEEL, Hanford, and other DOE sites

- $\quad$ NQA-1 and NOG-1 certified crane vendor

- $\quad$ Ederer Cranes:

- $\quad$ Domestic manufacture

- $\quad$ Meets above criteria

- $\quad$ Extensive experience in nuclear industry

- $\quad$ Specialized in remote operation and hazardous environments

- $\quad$ Successful history of equipment at INEEL, Hanford, and other DOE sites

- $\quad$ NQA-1 and NOG-1 certified crane vendor

Conclusion:

Buy - ACECO and Ederer are the primary industry competitors when dealing with cranes in hazardous environments. They have both focused on the nuclear industry and have both built quality assurance programs that support the majority of specifications that are written. Their track records are both very impressive. 


\subsubsection{Gloveboxes}

Technical Requirements:

Provide radiological containment - not shielding, except at the interface to the closure cell wall

Accommodate maintenance and repair of all welding, nondestructive examination, and stress mitigation equipment

Provide a transport mechanism to deliver lids, spread rings, and associated equipment into the closure cell

Accommodate a remotely controlled manipulator arm

Accommodate utilities and control capability to maintain and test all the weld closure equipment

Load-in and load-out capability using the "Double Door Sealed Transfer System"

Remote viewing capability

Vendors/Capabilities:

- $\quad$ Diversified Metal Products:

- $\quad$ Can provide design and fabrication or build to performance specification/drawings (approximately $50 \%$ either way)

- Willing to work with us on specification and/or design for fabrication

- $\quad$ They have not fabricated a shielded transfer drawer mechanism, but are familiar with shielded designs

- $\quad$ Can provide manipulator arms and hoists in gloveboxes with complete control systems for operators

- $\quad$ Have fabricated numerous gloveboxes for the nuclear industry - typical is 32 weeks after receipt of order (ARO) (long lead items can extend this time)

- $\quad$ Premier Technologies:

- Can provide design and fabrication or build to performance specification/drawings

- Willing to work with us on specification and/or design for fabrication

- $\quad$ Familiar with shielding doors and transfer of materials into a Hot Cell environment

- $\quad$ Can provide manipulator arms and hoists in gloveboxes with complete control systems for operators

- Have fabricated numerous gloveboxes for the DOE complex - typical is 32 weeks ARO (long lead items can extend this time) 
- $\quad$ Absolute Control Systems, Inc.:

- $\quad$ Can provide design and fabrication or build to performance specification/drawings

- Willing to work with us on specification and/or design for fabrication

- $\quad$ Familiar with shielded transfer drawer type mechanisms for movement of materials and equipment into Hot Cells

- $\quad$ Can provide manipulator arms and hoists in gloveboxes with complete control systems for operators

- $\quad$ Have furnished numerous gloveboxes to the nuclear industry - typical is 6 to 8 months ARO (long lead items can extend this time)

Conclusion:

Buy - All vendors surveyed appear to have the capability to design and fabricate the glovebox.

\subsubsection{Master-Slave Manipulators}

Technical Requirements:

Rated as heavy-duty units

Fabricated from stainless steel materials (where practible)

Anti-contamination boot on the slave arm

Electrically driven indexing in the $\mathrm{X}, \mathrm{Y}$, and $\mathrm{Z}$ directions

Manually operated switches for the electrically driven indexing shall be on the master handle and functional at maximum load

Grip sensation at the master shall be proportional to the tong (fingers) squeeze effort

Motion locks for all three axis capable of restraining the manipulator in any position at the maximum rated load

Tamper lock for each unit that mount to the wall that will lock the master handle to prevent unauthorized use

Tape load signal capability available to signal when squeeze force exceeds limit

Remotely removable load hook with handling fixture

Power requirements of $120-\mathrm{Vac}, 60 \mathrm{hz}$, single phase with grounded power cable (15 amp circuit per pair) 
Vendors/Capabilities:

- $\quad$ Central Research Laboratories (CRL):

- $\quad$ Currently, CRL is the only domestic vendor that can supply master-slave manipulators. CRL has provided numerous master slaves across the DOE and nuclear industry complex in this country with a proven track record. They offer several different models depending on the specific requirements for the user's application. Depending on the model(s) specified and unique requirements, delivery can be in the 6-8 month ARO.

Conclusion:

Buy - Master slave manipulators can be used without modifications directly from the manufacturer.

\subsubsection{Overhead Electro-Mechanical Manipulator}

Technical Requirements:

Overhead mounted systems that provide motion in $\mathrm{x}-, \mathrm{y}-$, and $\mathrm{z}$-axes

Designed per CMAA-70.

Remotely separable electric manipulator attached at base of z-axis with 6 DOF, 11 feet of reach, and minimum 400 pound payload capacity at full extension (includes storage stand

Wrist of manipulator shall provide for interchangeable end effectors (gripper, hook, etc.)

Repeatability and accuracy of position within 0.063 - inch at the z-mast tool interface

Electro-mechanical interface from z-axis that can accommodate 3,000 pounds

Auxiliary 1-ton hoist mounted from trolley (y-axis).

Radiation resistant to $10^{8} \mathrm{Rad}$ accumulated dose.

Ability to be decontaminated by spray washing with water, nitric acid, and other standard decontamination fluids.

Redundancy of active component for fail-safe operation and retrieval from remote locations

Remotely maintainable design.

Integrated control architecture for teleoperated, telerobotic, or robotic modes

Open architecture control system based on Windows ${ }^{\circledR} 2000$ operating system with ethernet communications port

Domestic manufacture with 5-year minimum history of production of similar equipment preferred. 
Vendors/Capabilities:

- $\quad$ PaR Systems: PaR TR6350 System

- Domestic manufacture

- $\quad$ Meets above criteria

- $\quad$ Controllable using a variety of operator interfaces and user designed control schemes

- Wide adaptability of equipment to engineered tooling and interfaces, although interface information is held to be proprietary

- A wide variety of experience with similar equipment and systems in a multitude of industries

- This company is the industry standard, worldwide, for electromechanical manipulation within remotely operated (radiation) environments

Conclusion:

Buy - PaR Systems is the only domestic vendor of overhead electromechanical manipulation systems that meets the above criterion. 